\title{
National security, social cohesion and sustainable development: panacea to conflicts, violence and xenophobia
}

\begin{abstract}
The vulnerability of citizens of the same nationality and migrant groups to violence exploitation and mistreatment in some areas within the country and foreign countries along with the protection of their rights has been threat to national security. However, conflict, violence and xenophobia need some measures of explicit attention although expressions of sentiments against the practice are clearly on the rise even in countries where they are rampant. The paper provides short accounts of conflict, violence and xenophobia witnessed in Nigeria and other foreign countries. The ambiguities surrounding the concepts and crucial features that define conflict, violence and xenophobia, security and legal implications will be critically examined. The final part of the paper will examine the developmental consequences of rampant conflicts, violence and xenophobia for citizens while examining policy, security measures and options to tackle them. The paper discussed the core values of national security, social cohesion, development and impact on Nigerian society.
\end{abstract}

Keywords: conflicts, violence, xenophobia, national, security, social, cohesion
Volume 2 Issue $6-2018$

\author{
Adebayo Akinade \\ Director-General Institute of Security, Nigeria
}

Correspondence: Adebayo Akinade, Director-General Institute of Security, Nigeria, Email bayoakinade@yahoo.co.uk

Received: May 25, 2018 | Published: December 19, 2018

\section{Introduction}

Conflicts and Urban violence are now becoming more common than in the past, as Africa's rate of urbanisation is the highest in the world. Population is increasing dramatically in urban centres, while the economies of most African countries have been deteriorating. Thus, raising urban unemployment to a very high level. The youth (under 18 yrs) make up more than half the population of African countries. The governments are no longer spending money on the social sector-education, hospitals, housing and other urban social services - which have deteriorated dramatically during the last 15 years. These conditions in themselves are sufficient to provoke and sustain major and continuous violence in urban areas throughout Africa. ${ }^{1}$

Farming communities in Enugu, Ekiti, Delta, Bayelsa, Abia, Osun, Oyo, Ondo, Plateau, Benue, Nasarawa Taraba and Anambra states have been subjected to ceaseless attacks by herdsmen. Chief Olu Falae, a former Minister of Finance, was abducted in his Akure farm, while they slaughtered 40 people in Ukpabi-Nimbo in Enugu State in April 2016. In Delta State, women have staged nude protests against the imperious activities of the herders on their farmlands that have deprived them of farming. ${ }^{2}$

On the pretext of grazing cattle, they infiltrate farming communities and conquer such places through violence. An account said Fulani nomads killed about 800 people in Southern Kaduna villages between November 2016 and July 2017. The Director of Operations, State Security Service, Godwin Eteng, told a House of Representatives hearing that herdsmen import AK 47 rifles into the country, and stockpile them in Nasarawa, Benue and Plateau states. The 2015 Global Terrorism Index, compiled by a global think tank, the Institute for Economics and Peace, puts the issue bluntly. It described Fulani herdsmen as the fourth most deadly terrorist organisation in the world. In 2014, they killed 1,229 Nigerians, 847 of those casualties were in five North-Central states. The paper will examine how conflict, violence and xenophobia influence the relationship between ethnic groups, citizen migration and human development. The paper will further examine these connections with an emphasis on conflicts, violence, crime and xenophobia. The first section of the paper provides working definitions of conflicts, violence, crime and xenophobia and summarizes the methods by which they can be assessed. The second part of the paper reviews various approaches to explaining the phenomenon of conflict, violence and xenophobia. Examples from a variety of incidents and events in Nigeria and outside the country are provided to illustrate these approaches. Conflicts and violence against fellow nationals and foreigners constitutes a significant national security threat, domestic stability, peace and international reputation. The consequences of conflicts, violence and xenophobia for host and migrant populations as well as policy responses need effective and efficient security measures.

This paper assessed the implications of conflicts, violence, crimes and xenophobia in terms of shaping institutional responses. Developing effective institutional and social responses to such conflicts and violence requires an accurate and empirically-based understanding of the nature and causes of the conflicts and violence. In addition, understanding why certain responses are chosen over others requires an understanding of the political values and imperatives informing actions by important institutions such as law enforcement and security agencies. The assessments of the policies and roles during these conflicts and violence have been ambivalent at best identifying insufficient protection of victims, half-hearted investigations against perpetrators and in some cases outright collusion with attackers. There is the need for a specialised team be established. The patterns and trends in prevention and response planning be analysed to determine decisions to be taken The security architecture should develop an operational multi-agency preparedness plan and response for potential cases of widespread violence crime and conflict. Motivations are important means of understanding crime and violence patterns, identifying potential perpetrators and designing 
appropriate preventive responses. In the case of violence against some citizens in Nigeria any convincing discussion of motivations must focus on the following factors:

a) Who commit such violence, what pattern and trends and communities where it occurred?

b) Who are the targets of such violence and why these particular individuals or groups are targeted?

c) The various forms that the violence take

Criminal behaviour involving in the conflict and violence is deemed socially unacceptable, with criminals being outside the norm. The violence is usually characterized and conceptualized as crime. It follows that the response to it is a criminal justice response with a focus on policing. This is beneficial when it results in a show of force by the state of force by the state as a short-term preventive and response measures. The same effects are produced in a longer-term of security and preparedness.

\section{Concept and nature of xenophobia as element of conflict}

Despite its widespread usage, xenophobia remains an ambiguous term, it is derived from the Greek words 'xenos' and 'phobos' which corresponding mean 'strange or foreign' and 'phobia.' In the Concise Oxford Dictionary, Xenophobia is defined as a 'morbid dislike of foreigners. Scholars have conceptualized xenophobia in a number of ways. Berezin defines xenophobia as the fear of difference embodied in persons or groups. According to Nyamnjoh, xenophobia is the 'intense dislike, hatred or fear of others'. It has been characterized as 'an attitudinal orientation of hostility against non-natives in a given population'. ${ }^{3}$

And, it has been seen as 'hostility towards strangers and all that is foreign'. Another definition views xenophobia as 'attitudes, prejudices, and behaviour that reject, exclude and often vilify persons based on the perception that they are outsiders or foreigners to the community, society or national identity'. In some explanations, this prejudice extends towards non-citizens and other marginal groups. It can also be directed toward other ethnic minorities, including third or fourth generation descendants of immigrants. Another point of confusion is that xenophobia has been closely tied to racism and persists in newer characterizations of racism. Described as 'new racism', 'Differential racism', or 'cultural racism', cultural rather than racial differences become the basis of exclusion in newer forms. For others, xenophobia, unlike racism and nationalism, is a spontaneous, 'natural' biological reaction to strangers. Defined in such terms, xenophobia becomes a ubiquitous phenomenon which is difficult to challenge or confront. A variety of other terms to describe xenophobia have been developed including 'nativism', ethnocentrism, xeno-racism. ${ }^{4}$

Xenophobia is a form of attitudes based upon stereotypes of irrational fears of 'the other'. Xenophobia is 'fear' and hatred of strangers or foreigners or of anything that is strange or foreign. Beliefs and prejudices are difficult, if not impossible, to change through law, although legislation can and sometimes does strive to promote tolerance and harmony through teaching and other promotional measures. ${ }^{3}$

In general the existing legal standards aim to combat the manifestations of violence and xenophobia or incitement to discriminate in or violence motivated by fear or hatred of foreigners or other groups. It is important that measures neither intended to combat violence, conflict and xenophobia nor contribute to the problem instead of to a solution. The appearance of control measures often alleviates fears and reduces tensions between minorities and the majorities. However, at an extreme, the measures can violate the human rights of individuals under both the resentment of migrants and xenophobic action in the global South is not a new phenomenon. ${ }^{5}$

The expulsion of 800,000 Ghanaians from Nigeria in the 1980s, for example, was a clear early example of a people and government who had become increasingly inhospitable towards migrants from another African country. However, intolerance does appear to have become more widespread and intense as South-South migration has increased. Similar incident happened in 1969, when Ghanaian Government ordered that all aliens in Ghana should leave Ghana within two weeks in order to fulfill promise made by Ghanaian President then, Dr. Kofi Busia. This order adversely affected Nigerian traders in Ghana.

The contemporary resurgence of intolerance and xenophobia presents a formidable challenge to policy-makers and states. There can be no doubt that xenophobia destabilizes and seriously undermines the potentially beneficial relationship between international migration and human development. It acts as one of the major obstacles to maximizing the economic and social benefits of international migration, affecting both migrant and host populations adversely in many different ways. Escalated levels of xenophobia towards migrants and refugees directly contribute to the vulnerability and exploitation of these groups leading to marked inequalities in the long-term between migrant and non-migrant populations. In a broader sense, xenophobia undermines principles of human equality, social justice, and social cohesion. ${ }^{6}$

\section{South African xenophobia and Nigerian internal xenophobia}

It has become an annual ritual - just like an annual epidemic-for South Africans to engage in xenophobic attacks against their fellow Black Africans resident in South Africa. There are some trends in these attacks. The South Africans do not attack the Indians who have lived in South Africa for a couple of centuries. They do not attack the Pakistanis or the Chinese. They do not attack the North Africans. They do not attack the Whites who have settled in South Africa for centuries and are in control of the economy and the lands. The reason is simple. The colour of the skin of the above-mentioned people is different from that of the Black South Africans. The Black South Africans still see those with a different colour as superior prefer to vent their anger and frustration on their fellow Blacks who reside in South Africa to eke out a living. ${ }^{7}$

Coincidentally, the xenophobic attacks have been occurring in the tenure of President Jacob Zuma. They did not occur when Dr Nelson Mandela or Mr. Thabo Mbeki were in office. One can infer that the body language of Zuma has been encouraging the attacks. Maybe, if he had shown some righteous anger against the attacks or ensured, that the perpetrators are severely punished they would not have recurred. Ironically, Nigerians have been expressing their anger over the xenophobic attacks. Many commentators remind South Africans the sacrifices Nigeria and other African nations made to end apartheid in South Africa, including hosting many leaders of the African National Congress as well university students from South Africa. However, the reason the action of the South Africans is shocking to many Nigerians is that we have a track record of not attacking foreigners better than they treat fellow Nigerians. ${ }^{\text {? }}$ 
For example, in spite of the number of times Nigerian football clubs and national teams have been attacked while in other countries, Nigerians usually don't attack foreign teams. On the contrary, on many occasions, during some international matches, Nigerian football fans are known to have swapped support from the national team to the visiting teams if they are not impressed with the performance of the national team. Even if a visiting team beats the Nigerian team or prevents Nigeria from qualifying for an international competition, such a team can even take a victory lap round the stadium without even a bottle of water thrown at them. However, among Nigerian ethnic groups, this has not been the case. There have been repeated ethnic-cum-religious attacks by natives on settlers, especially in the Northern part of the country. The first record of such attacks was on June 22, 1945 Jos over fear of domination by Southerners. It was followed on Saturday, May 16, 1953 by the attack in Kano, which occurred as a result of the motion moved by Chief Anthony Enahoro for self-rule by 1956 as well as the planned tour of the North by Chief Obafemi Awolowo of the Action Group. Reports of inquiries into the attack showed that it was led by a Northern People's Congress' stalwart, Mallam Inua Wada, who complained that after the North had been booed and insulted in Lagos over their walking out of parliament in protest against Enahoro's motion for self-rule, the Southerners were planning to come to the North to mock them the more. Even though the planned tour of the Action Group was cancelled, the attacks still went on. Ironically, neither Enahoro nor Awolowo was Igbo, but those who bore the brunt of the mayhem were the Igbo. Then came the Mother of all Attacks in 1966, called the pogrom, in which about 50,000 Igbo were killed mainly in the North, following the 1966 military coups. That trend has continued almost every year since then to the present. However, one of such attacks should receive an award for being the most bizarre. In September 2005, a man made some cartoons of Prophet Mohammed in Denmark. In February 2006, riots erupted in some parts of Northern Nigeria with Christians (mainly Igbo) killed and their property destroyed. The ludicrous and ridiculous aspect of the attacks was that the Danish man had no connection with the Igbo: Denmark is in Europe while the Igbo are in Africa. The cartoonist is White while the Igbo are Black. Most of those attacked did not even know that such a man existed, neither did they know that he drew any cartoon. But the assumption was that since he was a Dane, he must be a Christian (not minding that he could be an atheist), and since the Igbo are mainly Christians, the anger should be visited upon them. And as usual, nothing was done to the perpetrators. The logical line of action should have been for the protesters to seek the Danish embassy or the United Nations' office and protest in front of it.

These attacks have some similarities with the South African attacks. The first similarity is that the attackers never target the Indians, Pakistanis, Chinese, or Whites. Because the attackers don't want to cause trouble for the state and the Federal Government, they don't even attack fellow Blacks from other African countries. They know that the affected countries will frown on such attacks. They limit the attacks to fellow Nigerians, especially from the South of the country and particularly from the South-East. Like the South African attacks, the attacks in the North have continued for decades because the body language of the leaders of the North as well as the leaders of Nigeria condones it. During any of such attacks, some people are arrested to please the media but shortly after, they are released quietly. A recent example is the lynching of 74-yearold Mrs. Bridget Agbahime on June 2, 2026 in Kano Some people were arrested and charged to court. In November 2016, the court freed all the suspects based on the legal advice from the attorney - general of Kano State to that effect. That marked the end of the case. It is just a matter of time for another group to kill some people somewhere. The perpetrators know that nothing will happen to them. The state governors will not want to take any action against them to avoid being politically unpopular. The Federal Government will not want to take any action to avoid offending the North. The matter is left to die a natural death. Anybody who talks about it is blackmailed by being accused of inciting the public and spreading hate. Those who killed others and burnt people's property are exonerated while those who condemn such unwarranted and unjust killings are demonised. Another similarity between the South African attacks and the Nigerian attacks is that just as the poor in South Africa have been made to believe that their poor status is caused by the Black Africans who are in their country "to steal their jobs", so also have the Northern poor been made to believe that their poverty is caused by the Southerners, especially the Igbo, who are in their land to "steal their jobs and opportunities." So, when both of these groups see the progress the settlers are making in their land and compare it with their own financial: status, it seems-to them that it is true that the settlers are the cause of their privation. Therefore, whenever there is an opportunity, they went their anger on these settlers, killing them, looting their property or destroying it. The government and leaders, who are indeed the cause of the poverty, take no serious action so as to continue to have scapegoats. ${ }^{7}$ One trait that Africans flaunt is their hospitality. A true African would deprive himself some pleasure to make a stranger comfortable. Attacking foreigners in one's community is not bravery but cowardice. Nigeria must stop treating attacks on its citizens within or outside its shores with kid gloves. The life of a human being is not $d$ a same as the life of a rat. A country's strength lies in the premium it places on the life of every of its citizen.

\section{Rural conflicts over resources: causes of crises of herdsmen and crop farmers}

Rural conflicts are conflicts- over grazing land, cattle, water points and cultivable land. These conflicts go back a long way, in some cases to the pre-colonial period. However, major changes have been introduced in the countries' economies such as changes over land laws which often contradict customary laws, confiscation of large tracts of land for ranching and large-scale farming, and increase in population. Most important is the rise of rural inequalities - between rich and poor and landless farmers, between rich ranchers and poor cattle owners. These changes have led to a considerable competition for the scarce resources of land (cultivable and grazing, including water). Furthermore, environmental deterioration in land productivity and scarcity of water has contributed to the intensity of the competition. ${ }^{8}$

Amongst pastoral societies in particular, the system of grazing which involves movement of large cattle herds to water points and in search of pasture, has created a serious problem. Private ownership of land has restricted these necessary movements of pastoralist and the impact has been serious and catastrophic on pastoralist societies. ${ }^{9}$

\section{Herdsmen and impending food shortage}

In recent weeks, the world's fourth deadliest terror groups, Fulani herdsmen, have consistently attacked several farmlands in the country. For instance, recently, the University of Ilorin, Kwara State's multimillion naira research and training farm was reportedly destroyed and the dam poisoned. Vice Chancellor of the institution, Professor Sulyman Abdulkareem, decried the wanton damage which the herdsmen did to the training and research farm by the herds of cattle that illegally prowl there. Not even the elite farmers in the country are exempt from the wanton and willful destruction orchestrated by the herdsmen: the farms of a former Secretary to the Government of the Federation and traditional ruler, Chief Olu Falae and a former Chief 
of Naval Staff, Admiral Samuel Afolayan, have been invaded many times. They both have sad tales to tell about the serial fires set to their farms by the herdsmen in a bid to make their herds to forage on the fresh and tender, sprouting tendrils after the fires. The farmers in Benue State, known for their prolific production of food crops like yams, have similarly been frightened off their farms in the wake of the violent massacre of their compatriots. And farmers elsewhere also share the fears of their Benue State compatriots. Farming has become a risky and life-threatening venture. ${ }^{10}$

For instance, recently, some herdsmen allegedly burnt down a 120 -acre farmland in a farm settlement in the Esa-Oke area of Osun State. According to media reports, the farmland had plantain, oil palm, mangoes and other economic trees planted there by farmers. In yet another incident, the herdsmen killed a farmer in Ekiti State while he was returning home from his farm. In the absence of any official rebuke of the aggression of the herdsmen, it would be foolhardy and suicidal for any farmer to continue tilling the land in the presence of the violent and murderous nomads. So, apart from the infamy which the Fulani herdsmen's violent invasions represent, they have also become an official signal for impending food shortage in the coming harvest season. If the county's farmers have been displaced from their farms now, it will be silly to expect any bounteous harvest from them. As a matter of fact, Benue yam farmers have reportedly issued a notice to Nigerians not to expect a bountiful harvest this year. ${ }^{11}$

For a country that is, in the main, dependent on crude forms of farming for food security, it is bothersome that the authorities have yet to find it imperative to address this issue, especially as the threats and invasions of the herdsmen seem to have their official endorsement The president, in the name of the statutory duties of the establishment which he heads, should be concerned with what this portends for national food security and therefore address the issue honestly. Why have the security agencies, statutorily under the executive arm of the government, been so hesitant in arresting the herdsmen? Could it be because of their ethnically unbalanced composition? What will become of the livelihoods of the affected farmers after they have been displaced by the marauding herdsmen? Are there plans to compensate and rehabilitate them? What steps are being taken to cushion the effects of the impending food shortage that is so assured? What plans are in place to bring down the prices of food items during the food shortages? Will the consumers bear the brunt exclusively? There must, we insist, be a plan to address the issue of food shortage that is expected following the breach of security which the nefarious activities of the herdsmen have constituted and the president should consider himself obliged to assure the country. We expect him to be proactive in these matters as they touch on the existence of those who have fortuitously remained alive despite the rampage and infamy of the herdsmen.

\section{Implementing states' anti-open grazing laws}

Stiff opposition is building against the move by some states to forbid open grazing in their territories. This is principally because Fulani herdsmen, who are entombed in a time warp of roaming their cattle unchallenged, feel boxed into a corner by new laws being rolled out by state governments banning the practice. The herdsmen, under their umbrella body, Miyetti Allah, have threatened anarchy in these states. The law, first, by Ekiti State, and now Benue, is a last resort to the menace. In the course of engaging in their livestock business, nomadic Fulani herdsmen have caused unspeakable destruction to lives and property. Plateau, Benue, Kaduna, and Taraba (which is finalising its own anti-grazing laws), are the hardest hit. In these places, herdsmen have maimed, raped, slaughtered people, and devastated farmlands. Recently, they invaded Riyom, Plateau State, leaving a trail of anguish and deaths. In 2016, they massacred over 500 people in Agatu communities in Benue State, before confiscating their farmlands. With the Federal Government and its security agencies watching idly as the herdsmen rampage through the land, state governments have been left with no other choice than to enact laws to eradicate open grazing. This is a welcome development. It resonates with the communities suffering torment from herders' impunity, whether in Adamawa, Taraba or Zamfara, where they massacred 100 people in April 2014 in Galadima village.

However, Miyetti Allah is opposed to this new legal regime in the affected states. All that matters to it is the sustenance of its livestock; human life does not count. To it, its members are free to roam their cattle anywhere in the country. Ranching, the contemporary antidote to open herding and conflict elsewhere, is interpreted as an antiFulani scheme. "Anti-grazing laws are nothing but populist agenda designed by visionless and desperate politicians to destroy our means of livelihood," Saleh Alhassan, Miyetti's secretary, railed. "These laws are oppressive and negative and are fundamentally against our culture as Fulani pastoralists." He is totally wrong. Cattle rearing are not superior to other economic activities; nor are the Fulani a special breed who must always have their way at the expense of other Nigerians. Therefore, the states experiencing destruction wrought by the herdsmen must firmly implement the anti-open grazing law. Fulani pastoralists have a legal duty to respect another people's right to property. No culture that violently appropriates the farmlands of other people can lay claim to peaceful coexistence. Cattle rearing are not different from other forms of agriculture. Globally, it is a multi-billion dollar business. It generates huge incomes and jobs from domestic sales, packaging and exports, peaceful cohabitation with farming communities, prevents rustling and expands milk production. ${ }^{12}$

In 2014-15, the beef cattle industry in Australia accounted for 21 per cent (11.5 billion) of the total gross value of farm production and 23 per cent of the total value of farm exports income, according to its Department of Agriculture. The Washington, DC-based North American Meat Institute says the meat and poultry industry, which is the largest segment of the United States agriculture sector, processed 32.2 million cattle in 2013 , employed 482,000 persons and paid combined salaries of $\$ 19$ billion. Conversely, a 2011 survey by the Ministry of Agriculture puts Nigeria's total cattle head at 19.5 million. To make up the deficit in milk production, for example, Nigeria imports milk worth $\$ 1.3$ billion annually, says Audu Ogbeh, the Minister of Agriculture and Water Resources. The cattle-grazing business should be commercialised. States with high population of cattle herders should encourage and support cattle farming and ranching. Open grazing is an infringement upon other people's legal right to enjoy the benefits of land ownership. Cattle should be grazed on the owner's land or on leased land, and not just anywhere. Livestock property interest should not be placed above national interest. Criminal charges should be brought against cattle herders who interfere with another person's legal property rights. The states that have enacted the antiopen grazing laws should not succumb to sentiments, but effectively enforce them. 


\section{Herdsmen terror: rising above ethnic violence}

As Nigeria's steady and seemingly inexorable drift into an abyss of anomie continues, it is difficult not to notice the striking resemblance between the way Boko Haram propped up in the not-too-distant past, by those in a position to have nipped its incipient danger in the bud, and the way the marauding Fulani herders are being egged on in their sanguinary pursuits today. What is happening now, as was the case with the murderous Boko Haram group then, is a government adopting a policy of appeasement, or even turning a blind eye, in a situation that requires courage to deploy the full weight of the law to crush a certain and undisguised danger confronting the country. ${ }^{12}$

This is really not surprising because Nigeria has an uncanny reputation for ignoring insidious signs of national disasters until they assume gargantuan proportions and start wreaking incalculable havoc on the country. Whenever such situations present themselves, rather than act swiftly and dispassionately, in national interest, the response has most often been coloured by politics, ethnicity and religion. This is still a sad reminder that, more than a century after the colonial powers unwisely yoked together a diverse multitude of nations and groups into a single entity, Nigeria is yet to attain the status of nationhood. Boko Haram and the Fulani herdsmen's terrorism remain the most vicious security threats facing the nation presently. But Nigerian leaders are approaching the matter the way Nero, a Roman emperor, acted when his country was under a serious security threat. Legend has it that he was fiddling, while Rome was burning. When the Boko Haram cancer started rearing its ugly head in 2009, the late President Umaru Yar'Adua was one of the few that knew the danger of allowing the dangerous group to fester. He ordered that it should be swiftly crushed. But after the initial onslaught, resulting in the death of its founder, Mohammed Yusuf, and hundreds of others, Yar'Adua soon took ill and eventually died; but his order to snuff out the Islamist group was not effectively carried out. Boko Haram would later become the most deadly terror organisation in the world by 2014 , according to the Global Terrorism Index. Not only has the terrorist group been credited with the death of over 100,000 people, it also carried out an audacious kidnap of about 272 schoolgirls, many of whom have yet to regain freedom. But as if contending with Boko Haram is not enough headache for one country, the Fulani herdsmen, designated the fourth deadliest terror group in 2014 by GTI, soon joined to effectively mark Nigeria out as the most terrorised country in the world. ${ }^{12}$

But Nigeria is in this sorry pass because of the role of some Northernelite who politicised the Boko Haram narrative just as they are doing with the Fulani herdsmen carnage. Even the tepid response of the Goodluck Jonathan's inept administration was frustrated by those who thought they could score political points using the unfortunate circumstances. A prominent champion of this cause was the former governor of Adamawa State, Murtala Nyako, who, in an infamous memo to the Northern Governors' Forum, accused the Federal Government of committing genocide and blaming it on "innocent" Boko Haram. Describing Boko Haram attacks as induced calamity, the retired vice-admiral attributed the mass killings of students and children in their schools' dormitories and examination halls, and the mass kidnapping of girls, to Federal Governments agents. Yet, these were acts for which the murderous group clearly claimed responsibility. Such wild claims by a supposedly respected elder left those with the responsibility of fighting terror in a quandary.
Nyako, a former Chief of Naval Staff, was just one among the elite cast of that gruesome drama. At a critical time when the group had just pulled off an incredible feat of bombing Nigeria Police headquarters in Abuja, in 2011, the Sultan of Sokoto, Sa'adu Abubakar in, also a retired senior military officer, warned against a military crackdown on the group, saying, "You cannot solve violence with violence." Two years later, the then presidential candidate, Muhammadu Buhari, granted an interview to Radio liberty where he also condemned the clampdown on Boko Haram. Buhari, who was quoted as saying that he did not support the declaration of a state of emergency in Borno, Yobe and Adamawa states, complained that the government was killing members of the Islamist sect and destroying their houses while giving special treatment to militants in the Niger Delta.

At a time when Boko Haram had started occupying large swathes of territory in the North-East, targeting its critics, some governors came out openly to apologise to the mindless killers. Some people even attempted to lure them into dialogue, with a view to granting them amnesty, which, in Nigeria, comes with monetary reward. Of course, this was a proposition that the Islamists, who were only interested in foisting Sharia, the strict Islamic law, on the country, were not ready to consider. It was only when Boko Haram started targeting mosques, Islamic clerics and even made attempts on the lives of the then Emir of Kano and the Shehu of Borno that they started taking the group seriously. By then, it was already late, and Muhammadu Shuwa, a retired major general, and some other prominent people, had been killed. Nigeria is in a very precarious state now because acts inimical to the security and wellbeing of the country are being condoned. As the Fulani herdsmen and militia are wreaking havoc across the country, the loud voices of condemnation that should be heard have been muffled by the politics of ethnicity and religion. There is hardly any part of the country that has not tasted the brutality of the group that specialises in sacking villages and in invading people's farms with their cattle. What the herdsmen do in some places is akin to ethnic cleansing.

Instead of condemning their killings, the Minister of Defence, Mansur Dan Ali, would rather blame the anti-grazing laws enacted by some states to protect their people. The Inspector-General of Police, Ibrahim Idris, whose duty it is to arrest the killers, also found it convenient to attribute the killing of over 73 people on New Year's Day to "communal dashes." It even took the government almost an eternity to react and almost two months after, the perpetrators have not yet been brought to book. While Boko Haram has been limited largely to the North-East, the herdsmen's threat is more widespread and can be felt even in the most southerly parts of the country. But, like Boko Haram, the destructive spirit of the herdsmen may eventually not be limited to their present targets. Very soon, those propping them up today may become their victims tomorrow. That is the time that the country will start voting billions of dollars to fight Fulani herdsmen terrorism. Now is the time to stop the arms-bearing herdsmen and the militia that are killing on their behalf. When a similar problem cropped up in Ghana, the security forces responded swiftly by chasing them out of the country. Some of those that left Ghana eventually found their way here. Nigeria should not be a dumping ground for terrorists. The government has a responsibility to protect citizens against any external aggression, be it from Fulani herdsmen or any other terror group. 


\section{The national security and sustainable development}

\section{Concept of development}

Development is realistically seen as a multi-dimensional process involving the totality of man in his political, economic, psychological and social realities of man in his political, economic, psychological and social realities among others". Development is a holistic phenomenon not a concept to be abridged in application or compartmentalized and approached as a un-idimensional process. Essentially it should be man-oriented and not institutional-oriented. If we focus our attention on the individual citizens we can then think of what he needs at a particular time and how he can combat a number of colonial legacies which have held him down. Development, more importantly must be conceived in the context of a particular social system. In other words, it is wrong and indeed injurious to conceive of development in terms of system or system suited for a different cultural milieu. ${ }^{13}$

When we talk about national development we are concerned about quality improvement in the various sectors of our national life such as the political, ethical, socio-psychological, and economic spheres of national existence, which combined, to define and assure quality and productive existence for the citizens of a country. It is the accelerated economic, administrative, social, political, cultural and industrial changes in a condition considered desirable to achieve the progress of civilisation. The crucial element in national development is the constant and joint effort by the citizenry to harness the force of nature and human potential for their own material well-being. ${ }^{14}$

\section{The concept of national security}

National security question involves a lot of issues. Practically touches on all spheres of human existence. The best way to approach it is from the systems theory perspective where a dislocation in any particular area of the system is bound to have an overlapping effect on other areas. It ranges from food security to issues of environmental degradation. It touches on health matters. It encompasses psychological security as well as arms security. ${ }^{15}$

A number of factors may expose a nation to danger. To that extent, national security may also be viewed as a multinational process is to safeguard national values. The most fundamental values of any nation is its survival, self-preservation, and self-perpetuation. A nation that is capable of protecting herself from harm equally enjoys immense capacity for enviable development. We may therefore posit that national security and national development are complementary and inseparable phenomena. They are mutually related. There can be security without real development and no development without security. It is vice-versa. ${ }^{16}$

\section{The Relationship between National Development and National Security}

Security is anchored on national development. On the other hand, development can be anchored on security. For instance, the case of violence like ethic crisis, vandalism of pipes and electrical poles, armed robberies, kidnapping and others that cannot be mentioned, have hindered development of some infrastructures and foreign investment. ${ }^{17}$

Two major factors easily undermine the society of any nation. They are injustice and corruption. These elements may manifest outright in the actions or inactions of the government (i.e. the executive, the legislative and the judiciary) in their relationship with the governed and they have great capacity to generate devastating ripple effects. ${ }^{18}$ Let us examine some cases before looking at other element. The evidence of the dismal state of national security can also be in what described as the diminishing standard of living and the deterioration of social infrastructure system. For instance, the roads, electricity, pipe born water, refineries, hospitals and schools have not been functioning at their optimum level. ${ }^{19-21}$

Egwu says that security calculus of the Nigerian state failed because it did not include vital aspects of social amenities. ${ }^{22-25}$ Thus, the Nigerian state could not meet the social, economic, or even the military conditions for national security. ${ }^{26-28}$ These are a clear indication that the core social values and physical infrastructure necessary for establishing and sustaining national security, nation survival and socio-political wellbeing of the people are not there. Some examples of the infrastructure that has remained in the chronic or permanent state of disrepair low performance and even stagnation thus consisting a several threat to the national security of the country include the country's airports, sea ports, oil refineries, inter-state highways, rails, bridges etc. Nigeria has demonstrated that it lacks the fundamental requirements for national security namely a major stockpile of strategic defence, civil or general-purpose infrastructure..$^{29-35}$ this situation exists due to lack of knowledge skills and vision concerning the requirements of true national security. This is compound by the fact that political manipulation and correction have led to the misuse, embezzlement and misappropriation of the vital material and resources needed to improve the infrastructure for guaranteeing genuine security. ${ }^{36-40}$

\section{Consequences of Insecurity to the Nigerian Nations}

A nation that is riddled with crisis and insecurity can hardly make progress. For one, genuine investors are scared away from such countries. ${ }^{41-45}$ this has in large part become the burden of governments in Nigeria. Government officials either at the states or federal level who have been wooing foreign investors for foreign direct investments have always had issues of the state of national security dominating their discussions with foreign investors rather than the potentials and opportunities that exists in the state. ${ }^{46-50}$ The foreign direct investors profile of Nigeria for the period 1990-2005 aptly reflects the dire economic consequences face by a nation riddled with insecurity. ${ }^{51-57}$

\section{Conclusion}

We have been able to establish that there is a common link between national security and national development. ${ }^{58-62}$ in consequences, any remedial attack on national development must therefore involve issues of national security. Where there is peace and safety there in progress. We propose as follows ${ }^{63-68}$

\section{Dialogue}

There is the important need to encourage health discussions among individuals, communities and the government. ${ }^{69-71}$ This will be helpful in understanding one another and identifying issues conflict and negotiating peaceful resolution. Situation of misunderstanding are situations that promote strive and crisis. Dialogue respects individual's views, opinion and sense of self-worth. Understanding raises value and productivity. When ${ }^{72-78}$ talked about liberation, it is in the area of encourage the individual to rediscover himself and believes in himself. ${ }^{79}$ that may, in point of fact, by what is needed to advance 
development. Peace is synonymous with security. No nation can afford to play with its own security. ${ }^{80-99}$ Emphasis on security therefore must not be limited force or hardware. It encompasses issues of injustice, food, good health care, and environment protection, tolerance and respect for human rights. It is a total package. ${ }^{100}$ National security is like personal survival, is the first law among nations. National security is the precursor for national development. ${ }^{101}$

\section{Acknowledgments}

None.

\section{Conflicts of interest}

The author declares that there are no conflicts of interest.

\section{References}

1. Crush J, Penaleton. Wade. 2004.

2. Punch Editorial. "Disarming AK-47s Bering Fulani Herdsmen”. Punch; 2018.

3. Berezin, Mabel. Xenophobia and the new nationalism. In: Gerard Delanty, editor. The SAGE Handbook of Nations and Nationalism. London: Sage; 2006.

4. Danso Ransford, Mc Donald, David A. Writing Xenophobia: Immigration and the Press in Post-Apartheid South Africa. Migration Policy Series No. 17, Kingston and Cape Town: SAMP; 2000. 1-27 p.

5. Jacobs, Sean, McDonald, et al. Understanding Press Coverage of Cross- Border Migration in Southern Africa since 2000.SAMP Migration policy series No 37, Kingston and cape Town: SAMP; 2005. $44 \mathrm{p}$.

6. Forties HD. Ethnic Conflict, Commerce, Culture, and the Contact Hypothesis. New Haven and London: Yale University Press; 1997. 20 p.

7. Sampson Ikemitang. When will the Killings of Nigerians in South Africa stop? View Punch: Punch; 2018.

8. Eze OC. Inter-State Conflicts and Conflict Resolution in the Gulf of Guinea, paper presented at an International Conference in Oil Policy in the Gulf of Guinea, 1st- $3^{\text {rd }}$.Yaounde, Cameroun; 2003.

9. Gilkes P, Plaut M. War in the Horn: The Conflict between Eritrea and Ethiopia. London: Royal Institute of International Affairs; 1999. 45 p.

10. Adedeji A. Comprehending and Mastering African Conflicts. London: Zed Books; $1999.400 \mathrm{p}$

11. Editorial. "Mindless Killings of Nigerians". Punch; 2018.

12. Amadi Sam. "Herdsmen Conflict: Neo-feudalism and its problems". View Point: Punch; 2018.

13. Ake C. Development of what? For what? A paper presented at a conference on Development Strategies in Africa of the 1970's. Tanzanaia: DSP; 1972

14. Whaites A. States in Development: Understanding State Building Working Paper. UK: Department for International Development; 2008. $24 \mathrm{p}$.

15. Ademola, 0 Popoola. Human Rights and National Security under the Nigerian Constitution.2013. 8 p

16. Walker WO. National Security and Core Values in American History. Newyork: Cambridge: University Press; 2009:167-293.

17. Abolurin A. Democratisation and Conflict Management in Nigeria. Ibadan: John Archers; 2010. 233 p.
18. Sampson Ikemitang. When will the Killings of Nigerians in South Africa stop? View Punch: Punch; 2018

19. Didier. Security and Immigration: towards a critique of the governmentality of unease. Alternatives. 2002;27:63-92.

20. Crush, Jonathan, Pendleton, et al. Regionalizing xenophobia? Citizen attitudes to immigration and refugee policy in Southern Africa. SAMP Migration Policy Series No. 30. Kingston and Cape Town: SAMP; 2004.

21. Hossay Patrick. Our people firs'. Understanding the resonance of the VlaamsBloks xenophobic program. Social Identities. 1996;2(3):34363.

22. Jalusic, Vlasta. Xenophobia or self-protection: on establishing the new 2002. $143 \mathrm{p}$.

23. Mojca, et al. Xenophobia and Post Socialism. Ljubljana: Peace Institute; 2010. p. 45-72.

24. Jolt, Daniele. Scapegoats and social actors. The Exclusion and Integration of Minorities in Western and Eastern Europe. Centre for Ethnic Relations, University of Warwick and Macmillan Press; 1998. $241 \mathrm{p}$.

25. Jureidini Ray. Migrant workers and xenophobia in the Middle East. Program Paper No.2. Identities, Conflict and Cohesion Program, Geneva: United Nations Research Institute for Social Development (UNRISD); 2003. $17 \mathrm{p}$.

26. Rydgren Jens. The logic of xenophobia. Rationality and Society 2004;16(2):123-148.

27. United Nations High Commissioner for Human Rights. Human Rights of Migrants, Commission on Human Rights Resolution 1999/44. Geneva: OHCHR; 1999. 4 p.

28. Crush Jonathan. The dark side of democracy: Migration, xenophobia and human rights in South Africa. International Migration. 2000;38(6):103-20.

29. Crush Jonathan. Immigration, xenophobia and human rights in South Africa, SAMP Migration Policy. Series No. 22, Kingston and Cape Town: SAMP; 2001.39 p.

30. Auvinen J, Kivimaki T. Towards more Effective Preventive Diplomacy. Lessons from Conflict Transformation in South Africa, University of Lapland, Faculty of Social Sciences, Working Papers. 1997;4:7.

31. Ayissi A. Territorial Conflicts. Wilson Centre; 2010.

32. Lionel Cliffe. The regional dimensions of conflict in the horn of Africa. Lyons, The Horn of Africa Regional Politics. JSTOR. 1999;20(1):89-111.

33. Collier P, Hans Binswanger. Ethnic Loyalties, State Formation and Conflict. A background paper prepared for the Africa in the 21st Century Project. World Bank. Washington: DC; 1999. 32 p.

34. Zegeye A, Tegen M. The Ethiopia-Eritrea Conflict: A Critical Observation. Occasional Paper 54, Institute for Global Dialogue; 2007. $45 \mathrm{P}$.

35. Idowu William O. Citizenship, alienation and conflicts in Nigeria. Africa Development. 1999;24(1-2):31-55.

36. Markus Kornprobst. The Management of border disputes in African regional sub-systems: comparing west Africa and the horn of Africa. The Journal of Modern African Studies. 2002;40(3):369-393.

37. Kornprobst. The Management of Border Disputes in African Regional Sub-systems. J. of Modern African Studies. 2002;40(3):382-383.

38. Kornprobst. The Management of Border Disputes in African Sub-systems. $376 \mathrm{p}$. 
39. Lamin AR. The Politics of Reconciliation in the Mano River Union: Challenges and Prospects for Peace Building. Occasional paper 45 Institute for Global Dialogue; 2004. $5 \mathrm{p}$.

40. Lyons T. The International Context of Internal War: Ethiopia/Eritrea, In: Keller EJ, Donald Rothchild, editors. Africa in the International Order: Rethinking State Sovereignty and Regional Security, Boulder, Co: Lynne Rienner Publisher; 1996. 85 p.

41. Leone Cliffe. The regional dimensions of conflict in the horn of Africa Third World Quarterly. 1999;20(1):89-111.

42. Lyons T. The Horn of Africa Regional Politics: A Hobbesian World. In Wriggins H, editor. The Dynamics of Regional Politics. New York: Columbia University Press; 1992. 240 p.

43. Gunther Schlee. Redrawing the Map of the Horn: The politics of difference. Africa: Journal of the International African Institute. 2003:73(3):343-368

44. Markus Kornprobst. The management of border disputes in african regional sub-systems: comparing west Africa and the horn of Africa. Journal of Modern African Studies. 2002;40(3):369-393.

45. Mawson A. Southern Sudan. A Growing Conflict: The World Today 1984. $21 \mathrm{p}$.

46. Hercules Jacobus Boshoff. Sudan's Old and New Conflicts: A Comparative Study, assignment presented in partial fulfillment for MPhil requirements. South Africa: University of Stellenbosch; 2005.

47. Nzongola-Ntalanja, G. The international dimensions of the Congo Crisis Global Dialogue. 2004;6:3-4

48. Ogachi, Oanda. Economic Reform, Political Liberalization and Ethnic Conflict in Kenya. Africa Development. 1999;20(2):83-107.

49. On the Description of Ethiopia as a Black Imperial State. 2005.

50. Farer Tom J. War clouds on the Horn of Africa: The Widening Storm, New York: Carnegie Endowment for International Peace; 1979. $183 \mathrm{p}$.

51. Lewis. A Modern History of Somalia: Nation and State in the Horn of Africa. New York: Longman; 1980.279 p.

52. Sanni, Yusuf Audu. Visionary Security Impact on National Security and Development. Modern History of Sudan. 2010.

53. Lyons, Thomas, Akhigbe Imobighe. The Management of National Security. Nigeria: Inaugural Lecture Services; 1998. 142 p.

54. Abubakar A. The Challenges of Security in Nigeria. Newswatch. 2005.

55. Amucheazi EC. Reading in social sciences: issues in National Development. Nigeria: Fourth Enugu Dimension Publishers; 1980. 150 p.

56. Arewa JA. Core National Values As Determinant of National Security and Panacea For The Crime Of Kidnapping And Abduction. Nigeria Institute of Advanced Legal Studies Laws.2016. 25 p.

57. Chen, Lincoln. Global Health Challenges for Human Security Cambridge: Harward University Press; 2003. 338 p.

58. Criminal code Act cap 77, Laws of the Federation of Nigeria, 1990. $150 \mathrm{p}$

59. Curran DJ, Renzetti CM. Theories of Crime. New York. Prentice-Hall Passion; 2008. 120 p

60. Dermer MK B, Baird RM. Civil Liberties V. National Security in A Postral. World New York: PROMETHEUS book; 2004. 387 p.

61. Garland D. The Culture of Control: Crime and Social Order in Contemporary Society. Chicago: University of Chicago Press; 2002. $336 \mathrm{p}$.
62. Houreld K. Ransoms Fuel Surge in Nigeria. Kidnapping: Washington Post; 2007. $221 \mathrm{p}$.

63. Mathew JT. Redefining security. New York: Foreign Affairs; 1989.

64. Nwakpa E. National Bar Association, Deplorers National Decay, Insecurity. The Guardian; 2000. 25 p.

65. O’ Brien S, French JL. Criminal Investigation: Child Abduction and Kidnapping. New York: Chelsea House Publications Passion: 2008. 400 p.

66. Oludare J. The Burden of Insecurity. In National Standard. 2004.

67. Osuntokim J. The Kidnapping and Murder in Ekiti State. The Nation Newspaper. 2010

68. Pattern NJ. National Security: Institutional Approaches Policy Models and Global Impacts (Defence Security and Strategy) New York: Nova science passion; $2010.9 \mathrm{p}$.

69. Penal code Act, 89 Laws of the Federation of Nigeria. 2004. 200 p.

70. White JR. Terrorism and Homeland Security: An Introduction. Belmount: Ca Wadsworth Publishing; 2008. 2-97 p.

71. Akande. Introduction to the Constitution of the Federal Republic of Nigeria. M Lagos : MIJ Professional Publishers; 1999. 544 p.

72. Adekoya CO. The Right to Life. in the book, Issues in Constitutional Law and Practice in Nigeria. 1996. 364 p

73. BO Nwabueze. Federalism in Nigeria under the Presidential Constitution London: Sweet and Maxwell; 1983.413 p.

74. Nwabueze, BO. Presidentialism in commonwealth Africa. London: C.C. Hurst and Company; 1974. 442 p.

75. Social Security in Nigeria, delivered as part of the $10^{\text {th }}$ Anniversary of the Nigerian Institute of Advanced Legal Studies. Lagos: 2012.

76. Ben Nwabueze. Democratisation. Nigeria: Spectrum Law Publishing. 2003. 416 p.

77. Uiju OIowu. Fundamental Objectives and Directive Principles of State Policy in Nigeria. in the book, Issues in Constitutional Law and Practice in Nigeria. 1996. 291 p.

78. Human rights and Democracy in Africa. $2017.78 \mathrm{p}$

79. Isawa Elaigwu J. Federalism, Institutionalization and Political. UK: Adonis \& Abbey Publishers Ltd; 1990. 21 p.

80. John A Wiseman. Democracy in Black Africa: Survival and Renewal. New York: Paragon House; 1990. 96 p.

81. Wheare KC. Federal Government. UK: OUP; 1956.58 p.

82. Pita Ogaba Agbese. National Security and Human Rights: The Foundation of a Stable Third Republic: Towards the Stability of the 3rd Republic. Indian University press.1999;37(3):23-44.

83. Kuteyi OS, Ogunfolu. The Legal and socio-Economic Implications of State Police in Nigeria.

84. Oyorbare, et al. Government: A Preparation Court. Evans Publishers, Ibadan; 1991. 28 p.

85. Dickson Dare Ajayi. Stability in Nigeria in the Context of vision 2010. African Journal of Federal Studies. 2007;1(1):341-365.

86. Sections 33-44. Constitution of Nigeria. 1999. 169 p.

87. Sagay IE. The 1999 Constitution and the Subversion of Federalism. 1997. 33 p.

88. Enhancing Security and Justice Service Delivery. OECD; 2007.26 p. 
89. Concepts and Dilemmas of State-Building in Fragile Situations. From Fragility to Resilience. OECD; 2008. 82 p.

90. Service Delivery in Fragile Situations: Key Concepts, Findings and lessons. OECD; 2008. 9(3):7-60.

91. State-Building in Situations of Fragility: Initial Findings. Paris: OECD; 2008. 4 p.

92. Armed Violence Reduction: Enabling Development. OECD; 2009. 140 p.

93. Saferworld. Creating Safer Communities: Lessons from South Eastern Europe. Balkan Youth Union, Centre for Security Studies; 2006. 45 p.

94. Sampson R. Neighbourhood and Community. Collective Efficacy and Community Safety, New Economy, Institute for Public Policy Research. 2004;11(2):106-113.
95. Stewart F, et al. Social Exclusion and Conflict: Analysis and Policy Implications. Oxford: Centre for Research on Inequality, Human Security and Ethnicity; 2005. 60 p.

96. UN-Habitat. Strategic Plan for Safer Cities 2008-2013. 2007.

97. World Bank. Community-Driven Development in the Context of Conflict-Affected Countries: Challenges and Opportunities. 2006.89 p.

98. World Health Organization. Preventing Violence and Reducing its Impact: How Development Agencies can Help. 2008. 60 p.

99. United Nations Development Programme. 2013.

100. Bureau for Crisis Prevention and Recovery. 2016. 